\title{
Advocates/ Legal Experts' Perspective on Effectiveness, Opportunities and Threats of Consumer Grievances Redressal Agencies
}

\author{
Effulgence \\ Vol. 16 No. 2 \\ July - December, 2018 \\ Rukmini Devi Institute of Advanced Studies \\ E-mail : effulgence@rdias.ac.in, Website : www.rdias.ac.in \\ http://effulgence.rdias.ac.in/user/default.aspx \\ https://dx.doi.org/10.33601/effulgence.rdias/v16/i2/2018/78-98
}

\section{Dr. Ishwar Mittal ${ }^{1} \measuredangle$ \\ Dr. Ravi Kumar Gupta²}

\begin{abstract}
This paper looks into the perception of advocates/legal experts towards consumer dispute redressal procedure effectiveness under Consumer Protection Act. It also examines the underlying opportuinities and threats affecting the functioning of Consumer forum. Consumer Protection Act has not made the compulsion of engaging advocates in consumer forum. Yet, they are the important functionaries in consumer grievances redressal mechanism. Descriptive research design was adopted for the study. The sampling unit was advocates/legal experts who plead at Consumer Disputes Redressal Agencies. Convenience cum purposive sampling was adopted for selecting respondents. The sample size was 50 respondents. A questionnaire was prepared for primary data collection. Various statistical tools and techniques viz. average, ratio, standard deviation, percentage, one sample t-test, Chi Square Goodness of Fit Test, Multi Dimensional Scaling (MDS) and Factor analysis using Principal Component Analysis used to analyze the data. Consumer cases were randomly dealt by the existing advocates. It was concluded by advocates' opinion that consumer forums were sufficiently effective in providing justice to consumers. Advocates viewed that consumer forums are easily accessible, provides hassle-free disputes redressal. It was explored that effectiveness of dispute redressal procedure at consumer forums was largely influenced by five factors viz. 'Fair Judgments', 'Consumer Friendliness', 'Ease of Disputes Redressal', 'Relevancy' and 'Forum Reliability'. Traditional \& innovative opportunities and dissonance $\mathcal{E}$ system insufficiency threats to consumer forums were worked out. Advocates stressed upon online registration of complaints and strong consumer movement as highly ranked innovative opportunity and traditional opportunity respectively. They described inactive consumer organizations and lack of awareness among consumers as highly ranked dissonance and system insufficiency threats respectively.
\end{abstract}

Keywords: Consumer Disputes Redressal Agencies, Advocates/ Legal Experts, Effectiveness of Consumer Forum, Opportunities, Threats.

1. Assistant Professor, Institute of Management Studies and Research, Maharshi Dayanand University, Rohtak, ishwarmittal@gmail.com

2. Professor, Department of Management Studies, Maharaja Agrasen Institute of Technology, Delhi, ravigupta29@gmail.com 


\section{INTRODUCTION}

C

onsumer Protection Act, 1986 (CPA) was meant to ensure that the consumers themselves argue their cases in a friendly atmosphere but the experience was different. With the opposite parties, manufacturers and service providers, hiring advocates, consumers are forced to follow suit. Frequent adjournments and long arguments in consumer cases are there with the presence of advocates. Advocacy is done to bring the social issues of marginalized, disadvantaged or unorganized sections of society to the person in authority to address issues. Advocates being the important participants of the Consumer Grievances Redressal Mechanism help in ensuring justice to the innocent. Consumer forums are not that effective as they ought to be. It may be due to several reasons. Effectiveness of consumer forums is very important to safeguard the interests of consumers. Consumer forums are meant to provide simple, speedy and inexpensive redressal. CPA provides the facility of defending the complaint directly by self or through advocates. The mechanism under CPA is free from procedural bindings of the court. Under Sec 13 (3A) of the CPA and the Consumer Protection (Amendment) Act, 2002, the authorities need to decide the complaint of consumers within 3 months or within 5 months (in case of analysis of sample).The Forums are not supposed to grant adjournment unless sufficient cause is shown and the reasons for grant of adjournment have to be recorded in writing by the forum. There are several opportunities and threats exist before the consumer forums in today's scenario. Opportunities and Threats analysis is a conduct to analyze external environment of any business and non- business organization. Computerization with CONFONET, availability of funds, strong consumer movement, consumers' non-awareness, community radio stations, online registration of complaints, inactive consumer organizations, fake complaints, disobedience with the final orders of consumer forum etc are some of the opportunities and threats before the forums. The basic problems and suggestion about consumer grievances redressal procedure can be better explained by the legal experts who are active in the area of consumer protection.

\section{REVIEW OF RELATED LITERATURE}

The study needs to understand the gap in research hence the following significant work done on the various aspects of consumer protection concering advocates has been reviewed here.

Jain (1999) studied the appraisal of district consumer disputes redressal forums in Haryana. He carried out a survey on functioning of 5 district forums of Haryana taking the data of 1993-1997. He suggested that frequent adjournment must be discouraged to achieve the purpose of justice. On adjournment issue, the policy should be not to grant adjournment for more than one time unless justified. He further suggested establishing consumer forums at sub division level by amending CPA for speedy disposal of cases \& justice at the doorstep. For depoliticization of consumer forums, he advocated to include one member from registered consumer organizations in operation for more than 10 years. Besides above, many suggestions regarding staffing, infrastructure, library, consumer awareness campaign, research etc. are also included in his study.

Ali (2010) dealt with the functioning of Consumer Dispute Redressal Agencies in the two districts of Goa namely North Goa and South Goa. He found that redressal agencies take approximately more than one year in disposing the complaints. Sometimes the complaint is pending for five to six years before these redressal agencies. The study cleared that there are three reasons for delay i.e. frequent adjournment, non appearance of opposite party and workload. Consumers and VCOs expressed that the procedure followed by the consumer forums is simple as compared to that of the ordinary courts. VCOs in Goa was satisfied with the procedure at forums but reported that justice is 
always delayed. Adjournments were primarily responsible for delay in justice.

Krishna and Suganya (2011) compared the performance of consumer courts (State Commission and 30 District Forums) in Tamilnadu with the consumer courts (State Commission and 14 District Forums) in Kerala from November 2009 to September 2010. The study revealed that consumer courts in Kerala were functioning more effectively than in Tamil Nadu. Apart from statistics, there were other factors, which influenced the effectiveness of consumer courts such as consumers' awareness level, their attitude and behavior, funds availability, support of state government concerned etc. Consumer courts termed like double edged swords with government and consumers on either side. Neither the government, nor the consumers can be individually blamed for any cause and benefit.

Kumar (2011) carried an empirical study on complainants to consumer forum in the Haryana. The study concluded that the $75 \%$ complainants lodged their complaints by engaging advocates. Complainants considered the complex and technical procedure as the most important factor for the slow disposal of cases in district forums and a very high percentage of respondents were in the grips of advocates regarding lodging of complaint in district forum. It was clear from the analysis that in the opinion of complainants that the accommodation of the district forum was sufficient for their efficient working. It was found that one third of the complainants would not like to file their complaints in the district forums, in case they are exploited in future. It was exhibited from the research that the procedure of filing the complaints in the forums was too technical, expensive and complex.

Singh (2012) studied the effectiveness of consumer forum and its Impact on corporate and consumers in U.P. region. He found that a huge backlog of pending cases was great cause of concern for both the Forums and pending cases seemed to have increasing every year. Collective agreement of aggrieved consumers with the factors of effectiveness of consumer forums was calculated and falls in the range of moderate agreement. It was observed that there was a huge difference in the views of different categories of respondents regarding the effectiveness of consumer forums. It was been inferred that difference between actual and expected effectiveness was insignificant. At the end, it was concluded that efficiency of the consumer forums was moderate, that is why these forums were not as effective as they supposed to be and needed to be improved for providing speedy and less expensive justice.

Misra, Chadah and Pathania (2013) sought to assess the impact and effectiveness of CPA. The study covered 5 states, 10 districts, and 50 villages. For 41.9 percent respondents, the source of information about the CPA was family and friends. Media as a source was indicated by 71.5 percent, lawyers by 13.2 percent. For 29 percent respondents, VCOs were the source of information about the CP Act. There was a broad consensus among the various stakeholders that the delay in disposal of cases was largely due to the involvement and appearance of lawyers in all cases. Because of this the proceedings have become too technical, cumbersome, and expensive as slowly the procedures of the civil court have crept in the proceedings of the district forums. It also revealed that 61.4 percent of the respondents would again file a complaint if the need be. Majority of the respondents believed that the Forums/ Commissions decide the cases only on merit.

Siddamma (2013) focused on the redressal mechanism established under CPA and problems faced by the governments in establishing this mechanism in the Bellary district of Karnataka. The research concluded that majority of the complainants and advocates were satisfied with the functioning of the forums and the forums were working efficiently in protecting the interests of the consumers. These forums were suitable and relevant in today's economic environment. These forums provided hassle free redressal of consumers' grievances. The 
justice was reported to be always delayed at these forums.

Sinha, Gupta \& Mittal (2015a) analyzed the attitude and perception of opposite parties towards consumer grievances redressal under Consumer Protection Act in Haryana. It was found that services of advocates were availed by most of the defendants. Defendants favoured the appointment of advocates at consumer forums. They justified it as advocates can represent the cases in more efficient and effective manner. Further the procedure complexities and technicalities at consumer forums can be better handled by advocates. Defendants were found satisfied with the procedure adopted for settling complaints at consumer forums.

Sinha, Gupta \& Mittal (2015b) revealed that even consumers hired the advocates to file cases at consumer forums but they did not desire to engage advocates. It was observed that consumers opposed the engagement of advocates because they demand heavy fees and unnecessarily delay the proceedings of consumer forums by taking adjournments. Some consumers defended the appointment of advocates because they felt that advocates can defend the case effectively more importantly, because the opposite party always engages the advocates. The logic seemed to be justified as a normal consumer is not that capable to argue against the seasoned lawyers.

Datt, Bhisham (2017) made a study on the base of secondary data to review the effectiveness of Consumer Protection Act, 1986. The author insisted on to make some new provisions to improve the effectiveness of Act. The number of dispute settlement bodies also should be increased. There should be more transparent method to file complaint and proceeding of judgment. The most important conclusion is lack of timely justice. Timely relief is the key of justice.

Sandhu, Amandeep Kaur (2017) studied the cases of unfair trade practices. After analyzing the Indian and global the social, economic and legal framework to deal with of unfair trade practices, the author presented the challenges being faced in India in relation to such practices. The author emphasized on the need for amendment in the current institutional set-up of the country. Consumer Protection Act, 1986 can be successful if lacunae in the act are removed. It needs effective implementation by the central and state government.

It is evident from above literature that no comprehensive study was undertaken in recent past on the opinion of advocates/ legal experts with respect to consumer grievances redressal mechanism in Haryana.

\section{OBJECTIVES}

- To assess the perception of advocates/ legal experts towards consumer dispute redressal procedure effectiveness under Consumer Protection Act in Haryana.

- To analyze the underlying opportuinities and threats affecting the functioning of Consumer Disputes Redressal Agencies.

\section{RESEARCH METHODOLOGY}

Considering to above objectives, descriptive research design was adopted for the study. The unit of sample for these objectives was advocates/ legal experts who plead at Consumer Disputes Redressal Agencies. Consumer Protection Act has not made the compulsion of engaging advocates in consumer forum. Yet, they are the important functionaries in consumer grievances redressal mechanism. A questionnaire was prepared on the basis of study of Singh (2012). The modifications were made in questionnaire form the study of Jain (1999). Ten advocates each from the ten randomly selected districts of Haryana were taken and total 100 questionnaires were mailed. The districts chosen were Bhiwani, Gurgaon, Hissar, Jhajjar, Karnal, Mahendergarh, Panipat, Rewari, Rohtak and Sonipat. Only 8 responses were received through mailed questionnaires. Then, 42 advocates of 
Bhiwani (18), Panipat (14) and Rohtak (10) were personally contacted. Considering the opinion of the experts in related field and reference of pevious studies, a sample size of 50 advocates/ legal experts was decided to be optimum for this study. Convenience cum purposive sampling was adopted for selecting respondents. Ten advocates each from the ten randomly selected districts of Haryana were taken and total 100 questionnaires were mailed. The districts chosen were Bhiwani, Gurgaon, Hissar, Jhajjar, Karnal, Mahendergarh, Panipat, Rewari, Rohtak and Sonipat. Only 8 responses were received through mailed questionnaires. Then, 42 advocates of Bhiwani (18), Panipat (14) and Rohtak (10) were personally contacted. The data were coded, tabulated and analyzed by using various statistical tools and techniques viz. average, ratio, standard deviation, percentage, one sample t-test, Chi Square Goodness of Fit Test, Multi Dimensional Scaling (MDS) and Factor analysis using Principal Component Analysis.

\section{DATA ANALYSIS AND INTERPRETATION}

\section{Profile of the Respondents}

The profile of the total sample of 50 respondents was analyzed in terms of work experience and gender. Advocates were categorised on the basis of their experiences in their profession. One category was of advocates who were having less than ten years of experience and another having more than ten years experience. 48 percent advocates were having less than ten years of experience and 52 percent advocates were having more than ten years of experience. The basic reason for choosing these categories was to randomize the findings with experienced advocates and young advocates. Most of the male advocates were found to be active in taking up the cases of consumer forums. 88 percent of the current sample was found to be male advocates while only 12 percent female advocates recorded their opinion.

Data collection was targeted for the advocates who have taken up the cases of consumer exploitation and pleaded at consumer forums. Few advocates/ legal experts who were having expertise in consumer matters have also been consulted to get better responses. 94 percent respondents were found to be taking up the cases of consumer exploitation. On the basis of purposive sampling, 6 percent respondents were also the experts of consumer related matters but did not directly deals with the consumer exploitation cases at consumer forums.

\section{Agreeableness with Dispute Redressal Procedure Effectiveness Related Factors of Consumer Forums}

Fourteen factors were selected for analyzing the underlying dimensions of dispute redressal procedure given under section 12 and 13 of CPA. The responses were recorded on the Likert's five point scale running from 'Strongly Agree' to 'Agree', 'Neither Agree nor Disagree', 'Disagree' and 'Strongly Disagree' and presented in the Table 1.

Table 1 : Agreeableness of Advocates with dispute redressal procedure effectiveness related factors of Consumer Forum

(1- Strongly Agree) (2- Agree) (3- Neither Agree nor Disagree) (4. Disagree) (5- Strongly Disagree)

\begin{tabular}{|c|c|c|c|c|c|c|c|c|c|c|}
\hline S. No. & Statement & 1 & 2 & 3 & 4 & 5 & Total & WMS & $\% \mathrm{WMS}$ & $\begin{array}{l}\text { Agree- } \\
\text { ableness }\end{array}$ \\
\hline 1 & 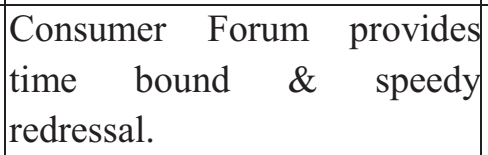 & $\begin{array}{c}1 \\
(2)\end{array}$ & $\begin{array}{c}2 \\
(4)\end{array}$ & $\begin{array}{c}2 \\
(4)\end{array}$ & $\begin{array}{c}12 \\
(24)\end{array}$ & $\begin{array}{c}33 \\
(66)\end{array}$ & $\begin{array}{c}50 \\
(100)\end{array}$ & 1.52 & 13 & S.D. \\
\hline 2 & $\begin{array}{l}\text { Consumer } \quad \text { Forum provides } \\
\text { inexpensive } \\
\text { Nominal Fees) }\end{array}$ & $\begin{array}{c}17 \\
(34)\end{array}$ & $\begin{array}{c}31 \\
(62)\end{array}$ & $\begin{array}{c}2 \\
(4)\end{array}$ & --- & --- & $\begin{array}{c}50 \\
(100)\end{array}$ & 4.3 & 83 & S.A. \\
\hline
\end{tabular}




\begin{tabular}{|c|c|c|c|c|c|c|c|c|c|c|}
\hline 3 & $\begin{array}{l}\text { Consumer Forum provides } \\
\text { hassle- free disputes redressal. }\end{array}$ & $\begin{array}{c}1 \\
(2)\end{array}$ & \begin{tabular}{|c|}
25 \\
$(50)$
\end{tabular} & $\begin{array}{c}7 \\
(14)\end{array}$ & $\begin{array}{c}15 \\
(30)\end{array}$ & \begin{tabular}{|c|}
2 \\
$(4)$
\end{tabular} & $\begin{array}{c}50 \\
(100)\end{array}$ & 3.56 & 64 & A. \\
\hline 4 & $\mid \begin{array}{lrr}\text { Dispute } & \text { redressal } & \text { under } \\
\text { Consumer } & \text { Forum } & \text { is } \\
\text { compensatory in nature. } & \end{array}$ & $\begin{array}{c}23 \\
(46)\end{array}$ & $\begin{array}{c}27 \\
(54)\end{array}$ & --- & --- & --- & $\begin{array}{c}50 \\
(100)\end{array}$ & 4.46 & 87 & S.A. \\
\hline 5 & $\begin{array}{l}\text { Consumer Forum is easily } \\
\text { accessible to all. }\end{array}$ & $\begin{array}{c}6 \\
(12)\end{array}$ & $\begin{array}{c}24 \\
(48)\end{array}$ & $\begin{array}{c}15 \\
(30)\end{array}$ & $\begin{array}{c}5 \\
(10)\end{array}$ & --- & $\begin{array}{c}50 \\
(100)\end{array}$ & 3.74 & 69 & A. \\
\hline 6 & $\begin{array}{l}\text { Dispute Redressal Procedure } \\
\text { in Consumer Forum is fully } \\
\text { transparent. }\end{array}$ & $\begin{array}{c}8 \\
(16)\end{array}$ & $\begin{array}{c}24 \\
(48)\end{array}$ & $\begin{array}{c}14 \\
(28)\end{array}$ & $\begin{array}{c}4 \\
(8)\end{array}$ & --- & $\begin{array}{c}50 \\
(100)\end{array}$ & 3.72 & 68 & A. \\
\hline 7 & $\begin{array}{l}\text { Processing of complaints is } \\
\text { technically very efficient. }\end{array}$ & --- & $\begin{array}{c}32 \\
(64)\end{array}$ & $\begin{array}{c}9 \\
(18)\end{array}$ & $\begin{array}{c}9 \\
(18)\end{array}$ & --- & $\begin{array}{c}50 \\
(100)\end{array}$ & 3.46 & 62 & A. \\
\hline 8 & $\begin{array}{l}\text { Consumer Forum acts very } \\
\text { strongly against frivolous and } \\
\text { vexatious complaints. }\end{array}$ & $\begin{array}{c}1 \\
(2)\end{array}$ & $\begin{array}{c}6 \\
(12)\end{array}$ & $\begin{array}{c}8 \\
(16)\end{array}$ & $\begin{array}{c}17 \\
(34)\end{array}$ & $\begin{array}{c}18 \\
(36)\end{array}$ & $\begin{array}{c}50 \\
(100)\end{array}$ & 2.1 & 28 & D. \\
\hline 9 & $\begin{array}{l}\text { Proceedings under Consumer } \\
\text { Forum are regular. }\end{array}$ & $\begin{array}{c}6 \\
(12)\end{array}$ & $\begin{array}{c}35 \\
(70)\end{array}$ & $\begin{array}{c}1 \\
(2)\end{array}$ & $\begin{array}{c}8 \\
(16)\end{array}$ & --- & $\begin{array}{c}50 \\
(100)\end{array}$ & 3.78 & 70 & A. \\
\hline 10 & $\begin{array}{l}\text { Consumer Forum provides } \\
\text { consensus judgment. }\end{array}$ & $\begin{array}{c}1 \\
(2)\end{array}$ & $\begin{array}{c}34 \\
(68)\end{array}$ & $\begin{array}{c}13 \\
(26)\end{array}$ & $\begin{array}{l}1 \\
(2)\end{array}$ & $\begin{array}{c}1 \\
(2)\end{array}$ & $\begin{array}{c}50 \\
(100)\end{array}$ & 3.66 & 67 & A. \\
\hline 11 & $\begin{array}{l}\text { Consumer Forum maintains } \\
\text { full accuracy in judgments. }\end{array}$ & $\begin{array}{c}1 \\
(2)\end{array}$ & $\begin{array}{c}31 \\
(62)\end{array}$ & $\begin{array}{c}13 \\
(26)\end{array}$ & $\begin{array}{c}4 \\
(8)\end{array}$ & \begin{tabular}{|c|}
1 \\
$(2)$
\end{tabular} & $\begin{array}{c}50 \\
(100)\end{array}$ & 3.54 & 64 & A. \\
\hline 12 & $\begin{array}{l}\text { Consumer Forum provides } \\
\text { fully impartial judgments. }\end{array}$ & $\begin{array}{c}1 \\
(2)\end{array}$ & $\begin{array}{c}29 \\
(58)\end{array}$ & $\begin{array}{c}16 \\
(32)\end{array}$ & $\begin{array}{c}3 \\
(6)\end{array}$ & \begin{tabular}{|c|}
1 \\
$(2)$
\end{tabular} & $\begin{array}{c}50 \\
(100)\end{array}$ & 3.52 & 63 & A. \\
\hline 13 & $\begin{array}{l}\text { Execution of final orders is } \\
\text { very strong. }\end{array}$ & $\begin{array}{c}6 \\
(12)\end{array}$ & $\begin{array}{c}32 \\
(64)\end{array}$ & $\begin{array}{c}4 \\
(8)\end{array}$ & $\begin{array}{c}6 \\
(12)\end{array}$ & \begin{tabular}{|c|}
2 \\
$(4)$
\end{tabular} & $\begin{array}{c}50 \\
(100)\end{array}$ & 3.68 & 67 & A. \\
\hline 14 & $\begin{array}{l}\text { This Agency is relevant } \\
\text { considering today's business } \\
\text { environment. }\end{array}$ & $\begin{array}{c}26 \\
(52)\end{array}$ & $\begin{array}{c}22 \\
(44)\end{array}$ & $\begin{array}{c}2 \\
(4)\end{array}$ & --- & --- & $\begin{array}{c}50 \\
(100)\end{array}$ & 4.48 & 87 & S.A. \\
\hline & Collective Agreement (\%) & 14.0 & $\mathbf{5 0 . 5 7}$ & 15.14 & 12.0 & 8.29 & & 3.54 & 63.42 & A. \\
\hline
\end{tabular}

Source: Primary Data; Figures in parentheses indicates percentage; S. D.=Standard deviation WMS = Weighted Mean Scores

After working out weighted mean scores (WMS) for each statement, each weighted mean score was converted into weighted mean score percentage value, so as to obtain an easily comprehensible picture of the agreement level for the contents of that particular statement among the advocates. Each weighted mean score was converted into weighted mean percentage score through following computation;

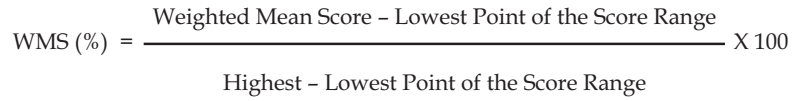

For interpreting WMS percentage values, a rating scale was used, according to which WMS percentage value:-

- The $\%$ WMS score up to $20 \%$ was considered as strongly disagreed (S.D.) meaning thereby 'consumer forum is ineffective'.

- The \%WMS score from $20.25 \%$ to $40 \%$ was considered as disagree (D.) meaning thereby 'consumer forum is less effective'.

- The \%WMS score from $40.25 \%$ to $60 \%$ was considered as neither agree nor disagree (N.A.D.) meaning thereby 'consumer forum is moderately effective'. 
- The \%WMS score from $60.25 \%$ to $80 \%$ was considered as agree (A.) meaning thereby 'consumer forum is sufficiently effective'.

- The \%WMS score above $80 \%$ was considered as strongly agree (S.A.) assuming that 'consumer forum is highly effective'.

Table 1 shows the collective agreement/ disagreement with the factors at different scales in last row. It reflects that only $14.0 \%$ advocates have expressed strong agreement with all the factors of effectiveness. Accordingly, dispute redressal procedure at Consumer Forums is very efficient and effective. A significant number of advocates (50.57\%) expressed merely agreement with said statements concluding thereby that consumer forums are sufficiently effective. A substantial number (15.14\%) of them revealed neither agreement nor disagreement concluding thereby that consumer forums are indifferent or moderately effective. 12.0\% advocates went with just disagreement with the stated factors. It can be described as consumer forums are less effective. Rests of them (8.29\%) expressed strong disagreement with these fourteen statements i.e. they have opined the procedure at forums as ineffective. Collective mean score (2.5), collective weighted mean score (3.54), collective percentage of weighted mean score $(63.42 \%)$ of all statements also describes that dispute redressal procedure of consumer forums is not strongly effective but it is sufficiently effective.

The respondents were strongly disagreed on one factor and rated forums as 'ineffective' on basis of that factor namely, (1) Consumer Forum provides time bound \& speedy redressal. They were disagreed on one factor and rated forums as 'less effective' i.e. (8) Consumer Forum acts very strongly against frivolous and vexatious complaints.

The respondents were agreed upon nine factors about consumer forums (see Table 1), accordingly rated forums as 'sufficiently effective' on basis of that factors. The respondents were strongly agreed about three factors of consumer forums (see Table 1) and termed theses forums as highly effective on the basis of these factors.

Table 2 : Descriptive statistics of dispute redressal procedure effectiveness related factors of Consumer Forum

\begin{tabular}{|c|c|c|c|c|c|}
\hline \multicolumn{4}{|c|}{ Descriptive Statistics } & \multicolumn{2}{|c|}{$\begin{array}{c}\text { One-Sample Test }(95 \% \\
\text { Confidence level })\end{array}$} \\
\hline S. No. & Statement & Mean & S.D. ( $\tilde{A})$ & t- value & Sig. (2-tailed) \\
\hline 1 & $\begin{array}{l}\text { Consumer Forum provides time bound \& speedy } \\
\text { redressal. }\end{array}$ & 4.48 & .909 & 11.514 & .000 \\
\hline 8 & $\begin{array}{l}\text { Consumer Forum acts very strongly against frivolous } \\
\text { and vexatious complaints. }\end{array}$ & 3.90 & 1.093 & 5.824 & .000 \\
\hline 3 & $\begin{array}{l}\text { Consumer Forum provides hassle- free disputes } \\
\text { redressal. }\end{array}$ & 2.84 & 1.017 & -1.112 & .272 \\
\hline 7 & Processing of complaints is technically very efficient. & 2.54 & .788 & -4.128 & .000 \\
\hline 12 & Consumer Forum provides fully impartial judgments. & 2.48 & .735 & -5.002 & .000 \\
\hline 11 & Consumer Forum maintains full accuracy in judgments. & 2.46 & .762 & -5.014 & .000 \\
\hline 5 & Consumer Forum is easily accessible to all. & 2.38 & .830 & -5.280 & .000 \\
\hline 10 & Consumer Forum provides consensus judgment. & 2.34 & .658 & -7.092 & .000 \\
\hline 13 & Execution of final orders is very strong. & 2.32 & .978 & -4.916 & .000 \\
\hline
\end{tabular}




\begin{tabular}{|c|c|c|c|c|c|}
\hline 6 & $\begin{array}{l}\text { Dispute Redressal Procedure in Consumer Forum is } \\
\text { fully transparent. }\end{array}$ & 2.28 & .834 & -6.105 & .000 \\
\hline 9 & Proceedings under Consumer Forum are regular. & 2.22 & .864 & -6.383 & .000 \\
\hline 2 & $\begin{array}{l}\text { Consumer Forum provides inexpensive redressal. } \\
\text { (Only Nominal Fees) }\end{array}$ & 1.70 & .544 & -16.898 & .000 \\
\hline 4 & $\begin{array}{l}\text { Dispute redressal under Consumer Forum is } \\
\text { compensatory in nature. }\end{array}$ & 1.54 & .503 & -20.506 & .000 \\
\hline 14 & $\begin{array}{l}\text { This Agency is relevant considering today's business } \\
\text { environment. }\end{array}$ & 1.52 & .580 & -18.045 & .000 \\
\hline
\end{tabular}

Source: Researcher's Compilation; S. D. = Standard deviation; Mean score $<3$ indicates Agreement towards that statement

Table 2 presents the mean values of various statements asked to get the opinion regarding dispute redressal procedure effectiveness of consumer forums.

The top 4 statements in Table 2 having mean value more than 2.5 are not agreed upon by advocates while other statements having mean score less than 2.5 indicate that these were agreed or strongly agreed by advocates. 'This Agency is relevant considering today's business environment' is most strongly agreed factor while Consumer Forum provides time bound \& speedy redressal is most strongly disagreed by the advocates.

To analyse the statistical significance of the statements, one sample t-test was applied. To decide whether the statement is statistically significant, the decision rule is $t \geq 1.960$ or $t \leq-1.960$ at $5 \%$ level of significance. From the Table 2, it was found that only one statement having $t$-value -1.112 is not statistically significant and rest 13 statements are statistically significant. The mean value of this statement indicates that the advocates have indifferent opinion regarding this statement.

Table 3 : Chi square Goodness of Fit statistics

\begin{tabular}{|c|c|c|c|}
\hline \multicolumn{2}{|c|}{ Chi Square Value } & df & p-value \\
\cline { 1 - 2 } Table Value & Calculated Value & 13 & .000 \\
\hline 22.362 & 122.029 & & \\
\hline
\end{tabular}

Chi Square Goodness of fit statistics is intended to test whether the observed data are inconsistent with the fitted model. After assigning the weights to all 5 ranks, results shown in the Table 3 are obtained.

$\mathrm{Ho}=$ All the fourteen statements are consistent for measuring effectiveness of dispute redressal procedure at consumer forums.

The tabulated value of chi square at 13 degree of freedom and at 5\% level of significance is 22.362 and the calculated value of chi square is 122.029 . In this case the null hypothesis is rejected and it can be concluded that the observed data were inconsistent with the estimated values in the fitted model since the $\mathrm{p}$ was significant, since $\mathrm{p}<0.05$. It can be concluded that there are statistically significant differences in above fourteen statements and these are not equally important for measuring effectiveness of dispute redressal procedure at consumer forums. Conclusion may be drawn from the analysis that fourteenth statement (This Agency is relevant considering today's business environment) was strongly agreed and most 
important and first statement (Consumer Forum provides time bound \& speedy redressal) was considered least important and strongly disagreed (see Table 2).

\section{Integration of Different Statements of dispute Redressal Procedure Effectiveness into Specific Dimensions (Factor Analysis)}

In order to identify the latent dimensions of dispute redressal procedure effectiveness, Principal component analysis (PCA) has been carried out among 14 statements included as above. PCA is a multivariate technique for transforming a set of related (correlated) variables into a set of unrelated (uncorrelated) variables that account for decreasing proportions of the variation of the original observations. As prerequisites, Kaiser-Meyer-Olkin (KMO) and Bartlett's Test of Sphericity have been employed. KMO measure verified the sampling adequacy for the analysis and Bartlett's test of Sphericity checked the intercorrelation among the statements. The value of KMO Measure of Sampling Adequacy came out to be .668 ('mediocre' according to Field, 2009) which is greater than 0.5 revealing that the factor analysis applied to the scale is appropriate (Malhotra, 2006). The value of Bartlett's test of Sphericity $\chi^{2}(91)=286.81, \mathrm{p}<.001$ (Field, 2009), indicates that intercorrelation between scale variables is sufficiently large for PCA.

To measure the effectiveness and reliability of scale, Cronbach's Alpha coefficient was used. The value of Cronbach's Alpha was found to be .785 which is well above the recommended level of .70 (Nunnaly, 1978; Gerrard, et al., 2006; Kenova \& Jonasson, 2006), indicating high reliability of the generated scale. Then, PCA was conducted on the 14 statements with Varimax Rotation method.

The value of communalities before and after extraction was checked under PCA method. The communality is the proportion of common variance within a variable. It measures the percent of variance in a given variable explained by all the factors jointly and may be interpreted as the reliability of the indicator. PCA works on the initial assumption that all variance is common; therefore, before extraction, all the initial communalities are 1 . The extracted communalities reflect the common variance or shared variance. If the communality for a variable is less than $50 \%$ than that variable needs to be excluded from the analysis because the factor solution less than half of the variance in the original variable, and the explanatory power of that variable might be better represented by the individual variable. In current analysis, communalities for all variables were above 0.50 , so none of the variables needed to be excluded on the basis of low communalities (see Table 4).

One of the most commonly used criteria for determining the number of factors or components to include is the latent root criterion also known as the Eigen value one criterion or the Kaiser criterion. With this approach, one can retain and interpret any component that has an Eigen value greater than 1.0. The latent root criterion was shown to produce the correct number of components when the number of variables included in the analysis is small (10 to 15) (Stevens, 1996; page 366). Alternatively, on the basis of proportion of variance accounted for, one can retain enough components to explain some cumulative total percent of variance, usually $70 \%$ to $80 \%$. In this study, five components were identified which supports the above criteria. Nearly $74 \%$ of the variance is explained by the five extracted components. And initial and final Eigen values for these five components were found to be more than 1 (see Table 4). All other components had the Eigen values less than 1 .

Table 4 shows the factor loadings after rotation. The principal component analysis resulted in a fivefactor extraction which indicates five underlying dimensions/ factors of consumer forums which can be generalized as mentioned in Table 4 . 
Table 4 : Rotated component matrix ${ }^{\mathrm{a}}$

\begin{tabular}{|c|c|c|c|c|c|c|c|}
\hline $\begin{array}{l}\text { Factor } \\
\text { Names }\end{array}$ & S. No. & Statements & $\begin{array}{c}\text { Factor } \\
\text { Loading }\end{array}$ & \begin{tabular}{|c|}
$\begin{array}{c}\text { Communa } \\
\text { lities }\end{array}$ \\
\end{tabular} & Eigen value* & $\begin{array}{c}\text { Variance } \\
\text { Explained }\end{array}$ & WMS \\
\hline \multirow{4}{*}{$\begin{array}{c}\text { Fair } \\
\text { Judgments }\end{array}$} & 12 & $\begin{array}{l}\text { Consumer Forum provides } \\
\text { fully impartial judgments. }\end{array}$ & 0.90 & .836 & \multirow{4}{*}{2.602} & \multirow{4}{*}{18.582} & \multirow{4}{*}{$\begin{array}{l}3.60 \\
(65.0 \%)\end{array}$} \\
\hline & 11 & $\begin{array}{l}\text { Consumer Forum maintains } \\
\text { full accuracy in judgments. }\end{array}$ & 0.82 & .848 & & & \\
\hline & 10 & $\begin{array}{c}\text { Consumer Forum provides } \\
\text { consensus judgment. }\end{array}$ & 0.62 & .641 & & & \\
\hline & 13 & $\begin{array}{l}\text { Execution of final orders is } \\
\text { very strong. }\end{array}$ & 0.56 & .542 & & & \\
\hline \multirow{3}{*}{$\begin{array}{l}\text { Consumer } \\
\text { Friendliness }\end{array}$} & 8 & $\begin{array}{l}\text { Consumer Forum acts very } \\
\text { strongly against frivolous } \\
\text { and vexatious complaints. }\end{array}$ & 0.79 & .654 & \multirow{3}{*}{2.506} & \multirow{3}{*}{17.900} & \multirow{3}{*}{$\begin{array}{c}2.45 \\
(36.25 \%)\end{array}$} \\
\hline & 1 & $\begin{array}{l}\text { Consumer Forum provides } \\
\text { time bound \& speedy } \\
\text { redressal. }\end{array}$ & 0.76 & .668 & & & \\
\hline & 5 & $\begin{array}{c}\text { Consumer Forum is easily } \\
\text { accessible to all. }\end{array}$ & 0.71 & .764 & & & \\
\hline \multirow{3}{*}{$\begin{array}{c}\text { Ease of } \\
\text { Disputes } \\
\text { Redressal }\end{array}$} & 7 & $\begin{array}{l}\text { Processing of complaints is } \\
\text { technically very efficient. }\end{array}$ & 0.87 & .803 & \multirow{3}{*}{2.173} & \multirow{3}{*}{15.522} & \multirow{3}{*}{$\begin{array}{c}3.83 \\
(70.75 \%)\end{array}$} \\
\hline & 4 & $\begin{array}{l}\text { Dispute redressal under } \\
\text { Consumer Forum is } \\
\text { compensatory in nature. }\end{array}$ & 0.74 & .644 & & & \\
\hline & 3 & $\begin{array}{c}\text { Consumer Forum provides } \\
\text { hassle- free disputes } \\
\text { redressal. }\end{array}$ & 0.64 & .829 & & & \\
\hline \multirow{2}{*}{ Relevancy } & 14 & $\begin{array}{c}\text { This Agency is relevant } \\
\text { considering today's business } \\
\text { environment. }\end{array}$ & 0.82 & .809 & \multirow{2}{*}{1.538} & \multirow{2}{*}{10.983} & \multirow{2}{*}{$\begin{array}{c}4.39 \\
(84.75 \%)\end{array}$} \\
\hline & 2 & $\begin{array}{c}\text { Consumer Forum provides } \\
\text { inexpensive redressal. (Only } \\
\text { Nominal Fees) }\end{array}$ & 0.72 & .743 & & & \\
\hline \multirow{2}{*}{$\begin{array}{c}\text { Forum } \\
\text { Reliability }\end{array}$} & 9 & $\begin{array}{l}\text { Proceedings under } \\
\text { Consumer Forum are } \\
\text { regular. }\end{array}$ & 0.79 & .780 & \multirow{2}{*}{1.499} & \multirow{2}{*}{10.710} & \multirow{2}{*}{$\begin{array}{c}3.75 \\
(68.75 \%)\end{array}$} \\
\hline & 6 & $\begin{array}{l}\text { Dispute Redressal Procedure } \\
\text { in Consumer Forum is fully } \\
\text { transparent. }\end{array}$ & 0.62 & .756 & & & \\
\hline
\end{tabular}

Factor 1- Fair Judgments: The rotated component matrix revealed that advocates perceived this factor to be the most important factor with the highest explained variance of $18.582 \%$. Four out of fourteen statements about consumer forums load on significantly to this factor. Hence it can be concluded that Fair Judgments at the consumer forums is the most crucial factor considered by advocates. Weighted mean score (3.60) and percentage of this factor $(65.0 \%)$ indicates that this factor is agreed upon by advocates and described that consumer forums are sufficiently effective.
Factor 2- Consumer Friendliness: It revealed to be the second most important factor with explained variance of $17.900 \%$. Three statements were loaded on to this factor. Weighted mean score (2.45) and percentage of this factor $(36.25 \%)$ indicates that this factor is disagreed upon by advocates and described that consumer forums are less effective.

Factor 3- Ease of Disputes Redressal: This is the next important factor, which accounts for $15.522 \%$ of the explained variance. Three statements were loaded on to this factor. Weighted mean score (3.83) 
and percentage of this factor $(70.75 \%)$ indicates that this factor is agreed upon by advocates and described that consumer forums are sufficiently effective.

Factor 4- Relevancy: This factor accounts for $10.983 \%$ of explained variance. Two statements load on this factor among fourteen statements. Weighted mean score (4.39) and percentage of this factor $(84.75 \%)$ indicates that this factor is strongly agreed upon by advocates and described that consumer forums are highly effective with this factor.

Factor 5- Forum Reliability: Two types of statements load on this factor and together account for $10.710 \%$ of the explained variance. Weighted mean score (3.75) and percentage of this factor $(68.75 \%)$ indicates that this factor is agreed upon by advocates and described that consumer forums are sufficiently effective.

Reliability analysis (see Table 4) was used to measure the consistency of a questionnaire. The Fair judgments, consumer friendliness and ease of disputes redressal subscales of the dispute redressal procedure scale variables had high reliabilities with Cronbach's $\mathrm{a}=.756 ; \mathrm{a}=.707$ and $\mathrm{a}=.701$ respectively. However, the relevancy and reliability subscales had relatively low reliability with Cronbach's $\alpha=.503$ and $\alpha=.565$ respectively.

\section{Opportunities/ Threats Analysis of Consumer Forum}

Opportunities and threats are considered to be positive and negative factors in external environment. Although Consumer Forum is not a profit making organization, but there are external factors which affect the functioning of Consumer Disputes Redressal Agencies (CDRA) to a great extent. It is the need of the hour to have this analysis as the key for longer and effective existence of CDRAs. Six factors each of opportunities and threats are drawn based on policy documents, websites and other published material along with consultation with some experts of consumer laws. The respondents ranked these factors as per their experience with the functioning of CDRAs. First rank was given highest weight and last rank was given lowest weight.

\section{Opportunities to Consumer Forum}

The rankwise identified opportunities are tabulated in the Table 5.

\section{Table 5 : Opportunities to Consumer Forum}

\begin{tabular}{|c|l|c|c|c|c|c|c|c|c|c|c|}
\hline S. No. & \multicolumn{1}{|c|}{ Opportunities } & $\mathbf{1}$ & $\mathbf{2}$ & $\mathbf{3}$ & $\mathbf{4}$ & $\mathbf{5}$ & $\mathbf{6}$ & Total & WS & WMS & Rank \\
\hline 1 & Establishment of CONFONET & 23 & 5 & 2 & 4 & 6 & 10 & 50 & 205 & 4.10 & 2 \\
\hline 2 & Available of frequent and more grants & 2 & 14 & 12 & 13 & 1 & 8 & 50 & 179 & 3.58 & 4 \\
\hline 3 & $\begin{array}{l}\text { Strong consumer movement in the } \\
\text { country }\end{array}$ & 10 & 12 & 16 & 7 & 3 & 2 & 50 & 213 & 4.26 & 1 \\
\hline 4 & Community radio stations & 0 & 0 & 5 & 5 & 14 & 26 & 50 & 89 & 1.78 & 6 \\
\hline 5 & Online registration of complaints & 11 & 11 & 8 & 2 & 16 & 2 & 50 & 193 & 3.86 & 3 \\
\hline 6 & $\begin{array}{l}\text { Establishment of consumer protection } \\
\text { councils }\end{array}$ & 4 & 10 & 7 & 17 & 10 & 2 & 50 & 175 & 3.50 & 5 \\
\hline
\end{tabular}

Source: Primary Data; Rank 1: Most Important; Rank 6: Least Important WS = Weighted Scores; WMS = Weighted Mean Scores 
The opportunities stated in Table 5 are explained below as per rank given by respondents:

Rank 1: Strong consumer movement in the country: Strong consumer movement through consumer rights and awareness promotional campaigns was termed as the biggest opportunity for the Consumer Forums. The Department of Consumer Affairs has been taking a number of steps to strengthen consumer movement in the country involving the State Governments, voluntary consumer organizations, consumer activists, etc. Consumers Awareness measures such as JAGO GRAHAK JAGO, SYANI RANI, GRAHAK DOST, Talk Show, Quarterly Magazine 'UPBHOKTA JAGRAN', Radio and video spots, News Paper Advertisements etc. has become immensely popular and is now being used by several departments to aware and communicate with consumers.

Rank 2: Establishment of CONFONET: Establishment of CONFONET was ranked second best opportunity for Consumer Forums. CONFONET is an abbreviation of Computerization and Computer Networking of Consumer Forum in Country. This network is designed to improve operational efficiency, co-ordination, accessibility and speed in judicial administration. Furthermore, CONFONET also aims establishment of information communication technology infrastructure at Consumer Redressal Forum all over India. In addition to this, this network aims at providing egovernance, transparency, systematizing of working and time bound delivery of justice to the consumers.

Rank 3: Online registration of complaints: Online registration of complaints was described as third best opportunity. Online registration of complaints at district level will reduce paper work and storage of complaint files, which occupy major space of Consumer Forums and this process will also be helpful in providing speedy, less-expensive and simple redressal to aggrieved consumers.
Rank 4: Available of frequent and more grants: Availability of frequent and more grants by Governments were ranked at number four. New grant was released from time to time by governments. This grant was provided for establishing adequate infrastructure and computerizing consumer forums, to make them technically efficient and effective. Implementation of released grants will ensure speedy, inexpensive and effective redressal to the consumers.

Rank 5: Establishment of Consumer Protection Councils: Consumer protection councils were being established at the district level under the Act to support Consumer Forum in protecting aggrieved consumers from malpractices and negligent behavior of sellers. Co-ordination between forums and councils will help in achieving objectives set under the Act namely, speedy, less expensive and hasslefree justice. This opportunity was ranked at number five. In Haryana, not much consumer protection councils were formed till now at district level.

Rank 6: Community Radio stations: Community radio is a radio service offering a third model of radio broadcasting in addition to commercial and public broadcasting. A Community Radio serves a particular community, in accordance with the locality of the radio station. India's first community radio based consumer helpline was launched at Nuh, Mewat, Haryana on January 15, 2014. This helpline would be managed by Mewat based community radio station 'Radio Mewat'. Community radio was assigned as the least popular opportunity by advocates.

Table 6 presents the mean values of various opportunities to consumer forums asked to rank according to their importance by the advocates. The top four opportunities having mean value more than 3 were described as not so important by respondents while other two opportunities having mean score less than 3 indicate that these were important opportunities. 'Strong consumer movement in the country' is most important opportunity while 
'Community radio stations' is least important opportunity described by advocates.

Table 6 : Descriptive statistics of opportunities to Consumer Forum

\begin{tabular}{|c|c|c|c|c|c|}
\hline & \multicolumn{3}{|l|}{ Descriptive Statistics } & \multicolumn{2}{|c|}{$\begin{array}{l}\text { One-Sample Test (95\% } \\
\text { Confidence level) }\end{array}$} \\
\hline S. No. & Opportunities & Mean & Std. Deviation & t- value & Sig. (2-tailed) \\
\hline 4 & Community radio stations & 5.22 & .996 & 15.765 & .000 \\
\hline 6 & Establishment of consumer protection councils & 3.50 & 1.344 & 2.631 & .011 \\
\hline 2 & Available of frequent and more grants & 3.42 & 1.444 & 2.057 & .045 \\
\hline 5 & Online registration of complaints & 3.14 & 1.678 & .590 & .558 \\
\hline 1 & Establishment of CONFONET & 2.90 & 2.092 & -.338 & .737 \\
\hline 3 & Strong consumer movement in the country & 2.74 & 1.322 & -1.391 & .171 \\
\hline
\end{tabular}

Source: Researcher's Compilation; Mean score $<3.0$ indicates highly ranked opportunities

To check the statistical significance of the stated opportunities, one sample t-test was applied. To decide whether the opportunity is statistically significant, the decision rule is $\mathrm{t} \geq 1.960$ or $\mathrm{t} \leq-1.960$ at $5 \%$ level of significance. From the Table 6 , it is found that three opportunities having t-values .590, .338 \& -1.391 respectively, are not statistically significant and rest 3 opportunities are statistically significant. The mean values $(3.14,2.90 \& 2.74)$ of these non significant opportunities indicate that the respondents have indifferent attitude towards these opportunities.

\section{Multidimensional Scaling (MDS) for Opportunities to Consumer Forum}

Multidimensional scaling is a mapping technique by which researchers can obtain quantitative estimates of similarity among groups of items. The outcome of MDS is a 'map' that conveys, spatially, the relationships among items, wherein similar items are located proximal to one another, and dissimilar items are located proportionately further apart. Multi dimensional scaling was used here for finding out the positioning of various opportunities to consumer forums taken up for this study. The statistical output was the Euclidean map; where in advocates' perceptions were visually represented.
A two dimensional map was selected as the output for ease of use. Assessment of reliability and validity was carried out by examining the Stress value and Rsquare. The stress value was found to be 0.0067 which is acceptable (Stress value less than .025 indicates a perfect fit; Malhotra \& Dash, 2011). The value of R-square was found to be 0.999 which is again acceptable (R-Square values of 0.60 or better are considered acceptable; Malhotra \& Dash, 2011). This illustrates that $99.9 \%$ of variance in the model is explained by the two dimensions (very good fit). Since the Stress and R-square values were acceptable, the study can be termed as reliable and valid.

Fig. 1 is the SPSS output of multidimensional scaling. Stress Value (Badness of fit): Stress value obtained $=0.0067$, Stress value needed $=0$ to $<0.025$ is perfect (Malhotra \& Dash, 2011).

Squared Correlation Coefficient (Goodness of Fit): $\mathrm{R}$ square obtained $=0.999, \mathrm{R}$ square needed $=0.6$ or more (Malhotra \& Dash 2011).

The spatial map in Fig. 1 was analyzed by examining the relative positions of the opportunities in different quadrants and the opportunities were categorized as under: 
Vertical axis at the top is categorized as High Ranked. High ranked were perceived as opportunities which was given the more weight by advocates.

Vertical axis at the bottom is named as Low Ranked. It describes the opportunities which were given the less weight by advocates.

Horizontal axis on the left side is marked as Innovative. These were perceived as modern opportunities which were not much prevalent at the time of data collection.

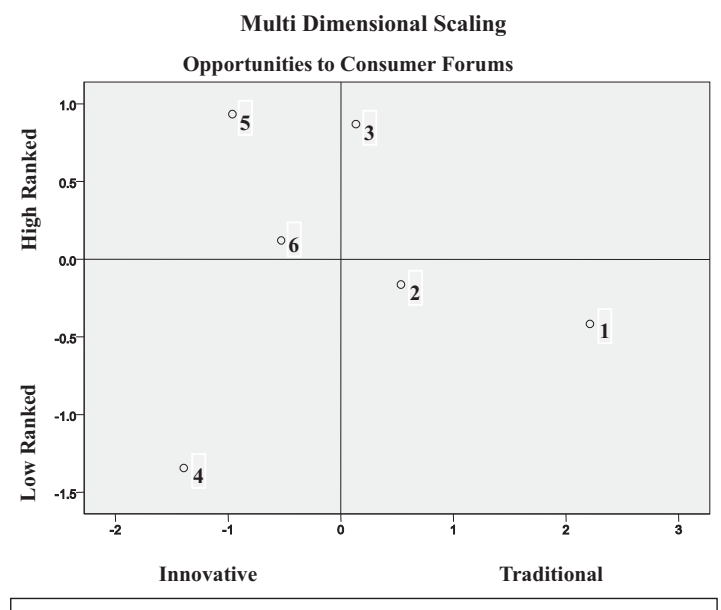

Fig. 1: Perceptual mapping of opportunities to Consumer Forum
Horizontal axis on the right is labeled as Traditional. Usually, these opportunities were found to be popular and contemporary. These opportunities were practiced for long time.

Online registration of complaints was marked as high ranked innovative opportunity for the consumer forums while Community radio stations was low ranked innovative opportunity. Strong consumer movement in the country was assigned as high ranked traditional opportunity while establishment of CONFONET was described as low ranked traditional opportunity by advocates. Establishment of consumer protection councils \& available of frequent and more grants could not be perceived by advocates with any particular dimension(s). These opportunities with their positions in middle of map indicate that consumer forums must regularly check with these opportunities for consistent performance.

\section{Threats to Consumer Forum}

All the consumer forums are bound to work under certain macro unfavorable conditions, known as threats. The rankwise identified threats are tabulated in the Table 6.

Table 6 : Threats to Consumer Forum

\begin{tabular}{|c|l|c|c|c|c|c|c|c|c|c|c|}
\hline \multicolumn{1}{|c|}{ Threats } & $\mathbf{1}$ & $\mathbf{2}$ & $\mathbf{3}$ & $\mathbf{4}$ & $\mathbf{5}$ & $\mathbf{6}$ & Total & WS & WMS & Rank \\
\hline 1 & Reluctance of advocates & 8 & 7 & 2 & 9 & 4 & 20 & 50 & 146 & 2.92 & 5 \\
\hline 2 & Filing of frequent fake complaints & 2 & 4 & 13 & 14 & 13 & 4 & 50 & 156 & 3.12 & 4 \\
\hline 3 & Limited funds & 2 & 14 & 12 & 10 & 9 & 3 & 50 & 181 & 3.62 & 3 \\
\hline 4 & Lack of Awareness among consumers & 27 & 10 & 4 & 3 & 2 & 4 & 50 & 245 & 4.90 & 1 \\
\hline 5 & Consumer Organizations are not active & 10 & 12 & 13 & 6 & 7 & 2 & 50 & 206 & 4.12 & 2 \\
\hline 6 & $\begin{array}{l}\text { Disobedience with the final orders of } \\
\text { consumer forum }\end{array}$ & 1 & 3 & 5 & 8 & 16 & 17 & 50 & 114 & 2.28 & 6 \\
\hline
\end{tabular}

Source: Primary Data; Rank 1: Most Important; Rank 6: Least Important WS $=$ Weighted Scores; WMS $=$ Weighted Mean Scores

The threats stated in Table 6 are explained below as per rank given by respondents:
Rank 1: Lack of awareness among consumers: Lack of awareness among consumers was the most prominent threat to consumer forums by advocates. 
It revealed from many studies that most of the general consumers were not aware about Consumer Dispute Redressal Agencies established under CPA. Moreover, awareness in rural areas was lesser than urban areas. Although, Government of India has launched many awareness campaigns but still these campaigns are not very successful and need to be promoted further.

\section{Rank 2: Consumer Organizations are not active: It} was ranked as second most important threat by advocates. VCOs form the backbone of consumer movement. In Haryana, VCOs are not found to be very active. Consumers are not aware about these organizations in their areas and do not take much help from them for the cases of their exploitation. In absence of these VCOs, the seller may not take care of the consumer rights and keep exploiting them.

Rank 3: Limited funds: Limited funds were provided by governments for Consumer disputes redressal agencies agencies. Due to limited funds, they have not got permanent judicial staff and facilities like full time courts. More funds need to be diverted to these agencies to improve facilities and provision need to be made to appoint the full time judicial staff. Advocates ranked this problem at third place as threat to the functioning of consumer disputes redressal agencies.

Rank 4: Filing of frequent fake complaints: There are many instances in which consumers filed fake complaints at consumer forums by misusing these consumer rights. Hence, filing of frequent fake complaints was described as one of the major threat by advocates and to discourage this habit of filing fake claims, intensity of fine or punishment need to be increased.

Rank 5: Reluctance of Advocates: Reluctance from advocate's side was cited as another threat that could unnecessarily delay the proceeding of consumer forums and this threat was ranked at fifth place. The finding reaffirms the findings of Singh (2012). Although, Consumer forums never asks the consumers to hire services of advocates, but due to advocates hired by opposite party, complainant has to take services of them because a common man cannot argue with advocate in technicalities. Once the case goes to advocates, they keep it delaying as long as their interests are served. To deal with this practice, some VCOs should be included to expedite proceeding for speedy redressal.

Rank 6: Disobedience with the final orders of Consumer Forum: Non-compliance with the final orders consumer forums was the sixth and last ranked threat for consumer forums. The finding is in contrast with the findings of Singh (2012) where this factor has got the first rank. This habit is prevalent among big companies who as opponents fail to comply with the final orders of consumer forums if the judgment is made against their interests and deliberately keep delaying order as long as possible. Consumer Forum were conferred with some judicial powers, but huge difference seems to have surfaced between theory and practice. Strong action need to be taken against defaulting parties for execution of the final orders in prescribed time limits.

Table 7 : Descriptive statistics for threats to Consumer Forum

\begin{tabular}{|c|l|c|c|c|c|}
\hline & \multicolumn{2}{|c|}{ Descriptive Statistics } & \multicolumn{2}{c|}{$\begin{array}{c}\text { One-Sample Test (95\% } \\
\text { Confidence level) }\end{array}$} \\
\hline S. No. & \multicolumn{1}{|c|}{ Threats } & Mean & Std. Deviation & t- value & Sig. (2-tailed) \\
\hline 6 & $\begin{array}{l}\text { Disobedience with the final orders of consumer } \\
\text { forum }\end{array}$ & 4.72 & 1.310 & 9.285 & .000 \\
\hline 1 & Reluctance of advocates & 4.08 & 1.947 & 3.923 & .000 \\
\hline
\end{tabular}




\begin{tabular}{|c|l|c|c|c|c|}
\hline 2 & Filing of frequent fake complaints & 3.88 & 1.239 & 5.020 & .000 \\
\hline 3 & Limited funds & 3.38 & 1.338 & 2.008 & .050 \\
\hline 5 & Consumer Organizations are not active & $\mathbf{2 . 8 8}$ & $\mathbf{1 . 4 5 2}$ & $\mathbf{- . 5 8 4}$ & $\mathbf{. 5 6 2}$ \\
\hline 4 & Lack of Awareness among consumers & 2.10 & 1.594 & -3.992 & .000 \\
\hline
\end{tabular}

Source: Researcher's Compilation; Mean score < 3.0 indicates highly ranked opportunities

Table 7 presents the mean values of various threats to consumer forums asked to rank according to their importance by the advocates. The top four threats having mean value more than 3 were described as not so important by respondents while other two threats having mean score less than 3 indicate that these were important threats. 'Lack of Awareness among consumers' is most vulnerable threat while 'Disobedience with the final orders of consumer forum' is least important threat described by advocates.

To check the statistical significance of the stated threats, one sample t-test was applied. To decide whether the threats are statistically significant, the decision rule is $t \geq 1.960$ or $t \leq-1.960$ at $5 \%$ level of significance. From the Table 7 , it is found that only one threat having t-value -.584 is not statistically significant and rest five threats are statistically significant. The mean value (2.88) of this non significant threat indicates that the respondents have indifferent attitude towards this threat.

\section{Multidimensional Scaling (MDS) for Threats to Consumer Forum}

As defined earlier, Multi dimensional scaling was used here for finding out the positioning of various threats to consumer forums taken up for this study. For this, a two dimensional map was selected as the output for ease of use. Assessment of reliability and validity was carried out by examining the Stress value and R-square. The stress value was found to be 0.0122 which is acceptable (Stress value less than .025 indicates a perfect fit; Malhotra \& Dash, 2011). The value of R-square was found to be 0.999 which is again acceptable (R-Square values of 0.60 or better are considered acceptable; Malhotra \& Dash, 2011).
This illustrates that $99.9 \%$ of variance in the model is explained by the two dimensions (very good fit). Since the Stress and R-square values were acceptable, the study can be termed as reliable and valid.

Fig. 2 is the SPSS output of multidimensional scaling.

Stress Value (Badness of fit): Stress value obtained $=0.0122$, Stress value needed $=0$ to $<0.025$ is perfect (Malhotra \& Dash, 2011).

Squared Correlation Coefficient (Goodness of Fit): $\mathrm{R}$ square obtained $=0.999, \mathrm{R}$ square needed $=0.6$ or more (Malhotra \& Dash 2011).

The spatial map in Fig. 2 was analyzed by examining the relative positions of the threats in different quadrants and the threats were categorized as under: Vertical axis at the top is categorized as Dissonance. Dissonance threats indicate the lack of agreement, cooperation and harmony between stakeholders of consumer protection and consumer disputes redressal system.

Vertical axis at the bottom is named as System Insufficiency. It describes the threats which show the inability of the redressal system to perform efficiently due system related deficiencies.

Horizontal axis on the left side is marked as High Ranked. These were perceived as more important potential threats by the advocates.

Horizontal axis on the right is labeled as Low Ranked. These threats were given less weightage by advocates. 


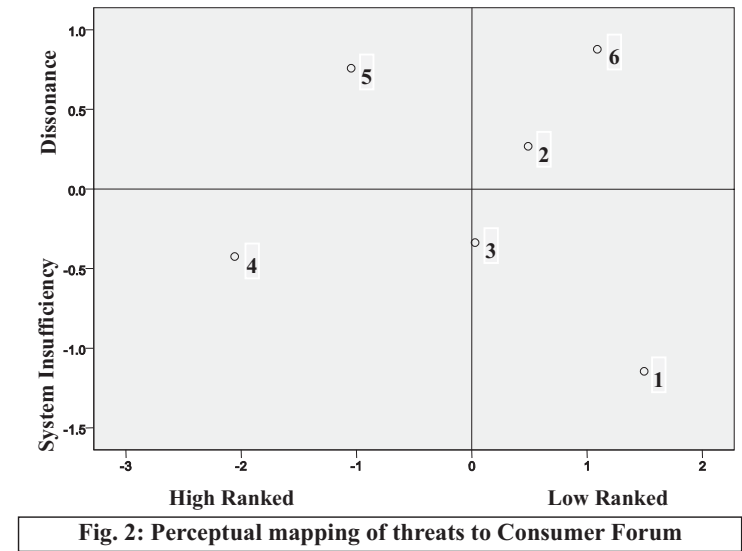

Inactive consumer organizations was marked as high ranked dissonance threat for the consumer forums while filing of frequent fake complaints \& disobedience with the final orders of consumer forum were low ranked dissonance threats. Lack of awareness among consumers was assigned as high ranked system insufficiency threat while reluctance of advocates was described as low ranked system insufficiency threat by advocates. Limited funds could not be perceived by advocates with any particular dimension. This threat with its positions in middle of map indicates that consumer forums must regularly check with this threat for consistent performance.

\section{CONCLUSIONS}

This paper examined the opinion of advocates/ legal experts towards effectiveness of consumer grievances redressal procedure under Consumer Protection Act in Haryana. Most of the advocates were found to be dealing in consumer cases along with other court cases. There were not any specialized legal experts of consumer matters found in selected respondents. This fact was also validated by advocates on verbal discussions with them. Consumer cases were not on their priority as lesser monetary incentive is involved in these cases (Krishna \& Suganya, 2011). Advocates were examined about dispute redressal procedure effectiveness at consumer forums. They reported that dispute redressal procedure of consumer forums is sufficiently effective (Singh, 2012; Siddamma,
2013). They strongly emphasized that consumer forum are far behind in providing time bound \& speedy redressal (Jain, 1999; Ali, 2010; Kumar, 2011; Misra et al., 2013). This observation was in contradiction to Siddamma, 2013. Advocates strongly viewed that this agency is very relevant considering today's business environment and provides inexpensive redressal (Siddamma, 2013). Consumer Forum did not act very strongly against frivolous and vexatious complaints. The good features reported were that these forums are easily accessible (Contradicted to Siddamma, 2013), provides hassle- free disputes redressal (Jain, 1999; Ali, 2010; Siddamma, 2013), fully transparent, technically efficient, regular in proceedings, consensus judgment, impartial and accuracy in judgments, and strong in execution of final orders. The study was supported by Singh, 2012. It can be concluded that dispute redressal procedure effectiveness at consumer forums was largely influenced by 'Fair Judgments', 'Consumer Friendliness', 'Ease of Disputes Redressal', 'Relevancy' and 'Forum Reliability'. Relevancy of consumer forums makes them highly effective while in case of consumer friendliness these were less effective. Fair Judgments, ease of disputes redressal and forum reliability were found responsible for making consumer forums sufficiently effective.

Consumer forums are not for profit making organizations. But in today's environment it has its own opportunities and threats. Opportunities can help these forums to improve their performance in a today's environment. Perceptual mapping of advocates was done. It shows that online registration of complaints was marked as highly ranked innovative opportunity for consumer forums. Strong consumer movement in the country was termed as highly ranked traditional opportunity while establishment of CONFONET was termed as low ranked traditional opportunity (Misra et al., 2013). Availability of frequent and more grants, establishing consumer protection councils (Misra et al., 2013) and community radio were termed as low ranked opportunities for consumer forums. These 
findings were opposite to the findings of Singh, 2012. Threats to consumer forums adversely affect their performance or achievement of its goals. Perceptual mapping of advocates shows that inactive consumer organizations' was highly ranked dissonance threat. Lack of awareness among consumers was assigned as high ranked system insufficiency threat. Filing fake complaints, reluctance of advocates and disobedience with the final orders were termed as low ranked threats for consumer forums. These findings were in contrast with the findings of Singh, 2012. Limited funds did not reported to be a great threat to the functioning of consumer forums.

Advocates provide the solutions to consumers' problems in more efficient way. Ignorance, illiteracy, poor knowledge of consumers forces them to take the assistance of advocates/ legal experts. Advocates' rationality, honesty with profession and fair justice to the aggrieved consumers are most important attributes to win the faith of consumers as complainants.

\section{REFERENCES}

1) Ali, G. S. 2010. Functioning of Consumer Dispute Redressal Agencies in the State of Goa: A Socio Legal Study with Special Reference to Services (Unpublished Ph.D. Thesis). Department of Law, Goa University, Panaji, Goa, India.

2) Datt, B. 2017. A Review of Effectiveness of Consumer Protection Act, 1986. International Journal of Emerging Research in Management \&Technology, Vol. 6 Iss. 2, pp.93-97.

3) Field, A. 2009. Discovering Statistics using SPSS (3rd ed.). New Delhi, India: SAGE Publications India Pvt. Ltd.

4) Gerrard P. J., Cunningham B. and Devlin J. F. 2006. Why Consumers are not Using Internet Banking: A Qualitative Study. Journal of Services Marketing, Vol. 20 Iss. 3, pp.160 - 168.

5) Jain, M. K. 1999. Consumer Disputes Redressal Forums in Haryana- An Appraisal of Their Working (Unpublished Ph.D. Thesis). Department of Commerce, Maharishi Dayanand
University, Rohtak, Haryana, India.

6) Kenova V. and Jonasson P. 2006. Quality Online Banking Services. Bachelor's Thesis in Business Administration. Jonkoping International Business School, Jonkoping University, Jonkoping, Sweden.

7) Krishna, B. Y. and Suganya, Y. 2011. A Comparative Study of Consumer Courts in Tamilnadu \& Kerala States- A Statistical Survey Report. Prabandhan: Indian Journal of Management, Vol.4 No.12, pp 45-54.

8) Kumar, S. 2011. Functioning of District Consumer Disputes Redressal Forums in Haryana- A Study of Three Districts (Unpublished Ph.D. Thesis). Department of Public Administration, Maharishi Dayanand University, Rohtak, Haryana, India.

9) Malhotra, N. K. 2006. Marketing Research- An Applied Orientation. New Delhi, India: Pearson Education.

10) Malhotra, N. K. and Dash, S. 2011. Marketing Research. New Delhi, India: Pearson Education.

11) Misra, S., Chadah, S. and Pathania, M. 2013. Evaluation Report on Impact and Effectiveness of Consumer Protection Act, 1986. New Delhi, India: Centre for Consumer Studies, Indian Institute of Public Administration.

12) Nunnally, J. (1978). Psychometric Theory (2nd ed.). New York: McGraw- Hill.

13) Sandhu, A. K. 2017. The Growing Problem of Unfair Trade Practices in India. International Journal in Applied Studies and Production Management, Vol. 3 Iss. 4, pp.75-83.

14) Siddamma, L. 2013. Working Method of Consumer Dispute Redressal Agencies with Special Reference to Bellary District Consumer Forum: An Analytical Study (Unpublished Ph.D. Thesis). Department of Post-Graduate Studies \& Research in Law, Gulbarga University, Gulbarga, Karnataka, India.

15) Singh, Y. 2012. Effectiveness of Consumer Forum and its Impact on Corporate and Consumers in U.P. Region (with Special Reference to Banking and Insurance Companies) (Unpublished Ph.D. Thesis). Faculty of Commerce, Dayalbagh 
Educational Institute, Dayalbagh, Agra, India.

16) Sinha, S.K., Gupta, R.K. \& Mittal, I. 2015a. Assessing Opposite Parties' Behavior towards Consumer Disputes Redressal Mechanism under Consumer Protection Act. Journal of People \& Society of Haryana, Vol. 5 No. 2, pp. 59-70.

17) Sinha, S.K., Gupta, R.K. \& Mittal, I. $2015 b$. Assessing Complainants' Perception of Consumer Grievance Redressal Mechanism under Consumer Protection Act. NICE Journal of Business, Vol. 10 No. 1\&2, pp. 73-92.

18) Stevens, J. 1996. Applied Multivariate Statistics for the Social Sciences (3rd Ed.). Mahwah, New Jersey, USA: Lawrence Erlbaum Associates Inc. pp. 366. 


\title{
Effulgence: Bi-Annual Management Journal of Management
}

\author{
Indexed and Listed at: \\ University Grant Commission (UGC) \\ J-Gate
}

\section{Guidelines for Authors}

Perspective

Effulgence is devoted to the publication of research papers/Book Reviews/Case Studies which advance knowledge through research and cases in functional areas of marketing, finance, human resource development, operations management, general management and also macro issues of globalization, regional trade and investment. The selection of papers for publication will be based on their relevance, clarity, and originality, the extent to which they advance knowledge, understanding, application and their likely contribution towards inspiring further development and research.

\section{Types of Contribution}

\section{Research Paper/Case Study}

The Journal attempts to maintain a balance between purely research-oriented papers and those derived mainly from the experiences of practitioners involved in the different areas of management. In case of research-based articles, papers that present the results of original research analysis are accepted for publication in the Journal. The managerial/policy implications of the study should be highlighted towards the end of the paper.

\section{Book Review/Scan}

This section covers abstract of books on management especially in the areas of skill building, managerial effectiveness, and macro-economic issues in development. The summary should not normally exceed 2000 words.

\footnotetext{
Abstract

The manuscript should be accompanied by an abstract (not more than 150 words) of the article and introduction of authors (name's, designation/s, affiliation/s) on separate sheets.
}

Text

The Research Paper/Case Study/Book Review should not normally exceed 6000 words. The articles should be in clear and concise English and should be typed on A4 paper in double-line spacing with wide margins. Papers submitted for consideration in Effulgence should be accompanied by a declaration by the authors that they have not been published or submitted for publication elsewhere. Editorial decision regarding articles accepted for processing in Effulgence will be communicated as per schedule in call for papers. We follow blind-refereed review.

\section{Copyright}

The manuscript should not appear in another publication. This will ensure copyright protection for both the authors and Rukmini Devi Institute of Advanced Studies. Note that it is the author's responsibility to obtain permission to reprint long quotations or use tables, figures or graphs previously published with copyright restrictions.

\section{General Outlines of Papers}

Your paper should contain the following items in the order shown below:

1. Title, author's affiliation and full address.

2. Abstract (not more than 150 words) outlining the purpose, scope and conclusions of the paper. The abstract should explain why the readers should consider these results important.

3. The text, suitably divided under headings and subheadings to elucidate the text and to emphasize points.

4. Acknowledgements, if any.

5. References.

6. Tables: Tables (each on a separate sheet) should be numbered consecutively in Roman numerals and should be referred to in the text as Table I, Table II etc. Tables should not duplicate results in graphs. 
7. Graphs: The minimum amount of descriptive text should be used on graphs and drawings (label curves, points etc. with single-letter symbols). Graph axes should be labeled with variable written out in full, along the length of the axes, with the unit in parenthesis.

8. Figures and illustrations (each on a separate sheet).

\section{References (APA Style)}

Only those references; which are actually utilized in the text, should be included in the reference list. In the text, references should be cited with the surname of the author(s) along with the year of publication, all in brackets. References should be complete in all respects and alphabetically arranged.

\section{Checklist}

While submitting the article please ensure that you have included the following:

1. The purpose and prospective readers for whom the article has been targeted, the significance of your contribution.

2. Appropriate context and background to your article by referring to earlier work in the area.

3. Practicality and usefulness of your work.

4. Implications of the study and Identification of future areas of work.

5. Proper structuring of the paper so that it reads in a clear and logical manner.

\section{Submission Guideline:}

1. Register as Author with user id and password on effulgence.rdias.ac.in

2. Wait for 3 working days for the activation of registration

3. If account is not activated email the issue on effulgence@rdias.ac.in and wait till approval.

4. If account is activated submit your research paper/book review/case study under the dropdown menu "Submit Article"

5. You can see further progress like review status, comment, etc. in your log in

6. Once the research paper/book review/case study is accepted for publication, submit the declaration form in your log in Dec. Form against your accepted research paper/book review/case study.

Please don't send the manuscripts through email as attachment, kindly submit online. We request authors to register first through our website effulgence.rdias.ac.in and use the link "Submit Articles" to submit your paper.

\section{Reference Citation}

Books:

Cooke, Helin S. and Tate, Karen (2005), "Project Management", Tata Mc Graw Hill.

Rothwell, William J. and Kazanas, H. C (2007), "Planning and Managing Human Resources", JAICO Publishing House.

\section{Edited Book:}

Rao, P. Mohana (2004), "Mergers and Acquisitions of Companies", Deep \& Deep Publication Pvt. Ltd.

\section{Articles in Edited Books:}

Gupta, S. (2001), "Financial Institutions and Economic Growth", in Problems and Prospects of Development Banking, ed. Atmanand, Delhi, International Books, pp. 412425 .

\section{Journal Article:}

Venkatrarnan, N. (1997), "Beyond Outsourcing: Managing IT Resources as a Value Center", Sloan Management Review, 38(3): 51-64 Kephart, J.Q. et al. (1997).

\section{Reports, etc:}

Centre for Monitoring Indian Economy (CMIE) (2000), Monthly Review of the Indian Economy, Mumbai, May, p.124.Reserve Bank of India (1989), Harmonizing the Role of Operations of Development Financial Institutions and Banks: A Discussion Paper, January.

\section{Newspapers:}

Tarapore,S.S. (1998). FIs' Days are numbered. Business Standard, 28 August.

\section{Managing Editor, Effulgence \\ Rukmini Devi Institute of Advanced Studies}

2A \& 2B, Phase-I, Madhuban Chowk, Rohini, Delhi 110085.

E-mail: effulgence@rdias.ac.in

Note: The opinions expressed in the papers published in Effulgence do not necessarily represent the views of Rukmini Devi Institute of Advanced Studies, Rohini, Delhi. Articles published in Effulgence should not be reproduced/ reprinted in any form without prior written permission. 